Max-Planck-Institut für demografische Forschung

Max Planck Institute for Demographic Research

Konrad-Zuse-Strasse 1 - D-18057 Rostock - GERMANY

$\mathrm{Tel}+49$ (0) 3812081 - 0; Fax +49 (0) 3812081 - 202;

http://www.demogr.mpg.de

MPIDR WORKING PAPER WP 2009-014

MAY 2009

\title{
Transfers, Consumption and Income over the Lifecycle in Germany
}

Fanny Annemarie Kluge (kluge@demogr.mpg.de)

This working paper has been approved for release by: Michaela Kreyenfeld (kreyenfeld@demogr.mpg.de), Acting Deputy Head of the Laboratory of Economic and Social Demography.

(C) Copyright is held by the authors.

Working papers of the Max Planck Institute for Demographic Research receive only limited review. Views or opinions expressed in working papers are attributable to the authors and do not necessarily reflect those of the Institute. 


\title{
Transfers, Consumption and Income over the Lifecycle in Germany
}

\author{
Fanny Annemarie Kluge*
}

July 8, 2009

\begin{abstract}
This paper seeks to quantify all public and private interage monetary flows in Germany applying the National Transfer Account method. Germany's lifecycle deficit is shaped by long periods spent in education, early retirement, and low labor force participation rates among the older work force, resulting in a rather short surplus period. Germany is a picture book welfare state, over the last century the government took over more and more functions the family would once have absorbed. During the long dependent periods of childhood and old age, the main expenditures-including education for younger people and pensions and health care for older people-are publicly financed. Private consumption is low for these items. In contrast to public in-kind transfers, public cash transfers are highly skewed to the elderly. Special emphasis will be placed on differences in East/West lifecycle deficit patterns.
\end{abstract}

\footnotetext{
* Max Planck Institute for Demographic Research, Konrad-Zuse-Str. 1, 18057 Rostock, Germany Email: kluge@demogr.mpg.de, Phone 0049-381-2081-210.
} 


\section{Introduction}

Throughout life, individuals show long periods of dependency (when consumption exceeds production) during childhood and old age (Lee et al., 2006). The required size of monetary flows to finance this dependency is large, intergenerational transfers amount to about one-half of national income (Mason, 2005). Generational Accounting (GA) was the first approach to study intergenerational relations in a broader concept. GA measures the burden imposed on future generations via public expenditure (Auerbach et al., 1991, 1992, 1994, 1999). GA restricts itself to the public sector and is a stock account that calculates the present value of net tax payments of all current and future generations. By indicating how changes in policies alter different generations' present expected values of their remaining lifetime net payments to the government, GA can determine the sustainability of welfare states. For Germany, GA in the baseline scenario finds an imbalance of the magnitude of $156,1 \%$ of net tax payments for future generations (Raffelhüschen and Walliser, 1999). Boll et al. (1994) find an imbalance of approximately the same magnitude (estimated for 2 different scenarios). GA estimates accounts for males and females separately and the age profiles do not change over time.

A more recent approach concerned with intergenerational relations is the National Transfer Account (NTA) Project. The theoretical roots are given by Samuelson (1958), Diamond (1965), Willis (1988), Lee (1994) and Bommier and Lee (2003). NTA incorporates public and private reallocation in a cross-sectional setting, based on a one year flow account, and includes the benefits from public goods. The accounting is consistent with the National Income and Product Accounts. An examination of the gap between consumption and income over the lifecycle leads to important insights about the social and economic institutions (e.g. what are the predominant redistributing institutions, magnitudes of different kinds of transfers, policy implications) that enable the economic flows between age groups that finance the large deficits at the beginning and the end of life (Lee et al., 2006; Mason, 2006). NTA provides a framework to study the implications of aging more closely, and the sustainability of policies can be evaluated (Mason, 2008b).

This paper seeks to quantify all public and private interage monetary flows in Germany applying the National Transfer Account method. Like in other welfare states, intergenerational transfers amount to a considerable share of GDP, with the public reallocation being more pronounced than the private reallocation mechanisms. Private intergenerational transfers amount to about $7,5 \%$ of GDP, with at least $10 \%$ of transfer to be intentional (Lüth, 2001). In addition to private transfers, public expenditure redistributes larger funds between age groups. Pensions for old age amount to $22 \%$ and public 
health spending for $17 \%$ of the public expenditure paid via large redistributions from those of working age to dependent age groups. The intergenerational redistribution is far more pronounced in Germany than the intragenerational, the German system emphasizes the insurance component over the welfare component (Boll et al., 1994). The key role of the state is especially valid for elderly people. $80 \%$ of their total income comes from public transfers (pensions) (Börsch-Supan, 1992; Reil-Held, 2002; Börsch-Supan and Schnabel, 1999). The reliance of pensioners on the state is even more pronounced in the former eastern part. Private transfer patterns also differ in East and West as examined in Kohli et al. (2006). After a brief introduction about the German economic and demographic situation as well as the social security system I will present data and methods used and the National Transfer Account results for Germany 2003 as well as selected findings for East and West separately.

\section{Germany}

Germany is the oldest welfare state in the world, having had social insurance since the 1890s. This institutional setting has also shaped the lifecycle deficit. Education is free of charge, and the periods of time spent in education are long, despite the availability of apprenticeships and the low rate of enrollment in tertiary education. The unemployment provisions for the elderly and the early retirement options introduced in the 1970s tend to encourage an early exit from the labor market. The needs of the dependent age groups are mainly publicly financed and amount to a considerable share of gross domestic product (GDP) for health, education, and pensions. The public transfer dependency is even higher in the eastern part resulting from historic reasons.

\subsection{Selected Demographic Facts}

With its 82 million inhabitants (38.1 million households), Germany is the most populous country and the largest economy in the European Union. Some 65 million people (31.0 million households) live in the western part of Germany, and 17 million (7.1 million households, including those in Berlin) live in the eastern part. After the baby boom of the 1950s and 1960s, the total fertility rate (TFR) dropped below replacement level in the early 1970s. The current rate of around 1.3 births per woman has remained stable for the past several years. During the period immediately following reunification the TFR in the eastern part of the country dropped between 1989 and 1995 from 1.56 to 0.84 (it has recently reached western values); nuptuality showed an even larger drop (Grünheid 


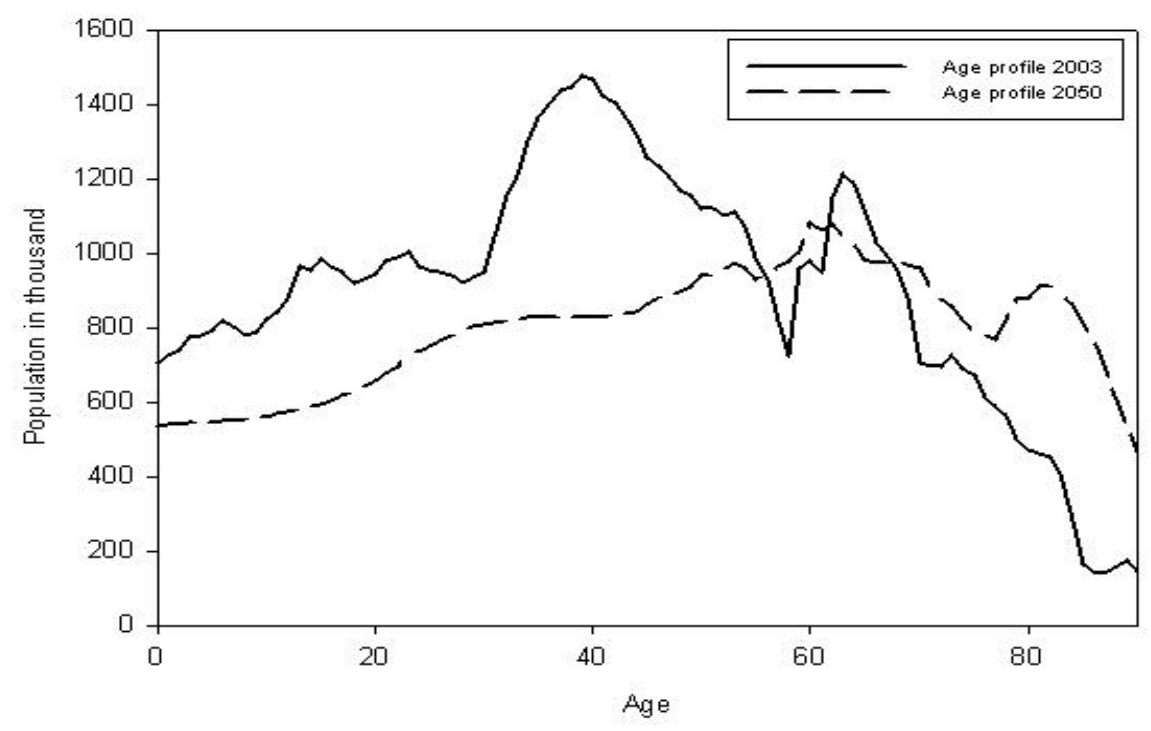

Figure 1: Age profile Germany, 2003 and 2050

Source: Statistisches Bundesamt (2006a)

and Mammey, 1997). Mean age at childbearing is 29.1 years. The low fertility rates are coupled with a rising life expectancy at birth: 76.2 years for men and 81.8 years for women in 2003. Rising life expectancy and low fertility levels have resulted in an old-age dependency ratio of 25.9 per 100 inhabitants of ages 20-64. This is among the highest in Europe, and it is expected to increase to slightly over 50 by $2050 .{ }^{1}$ Figure 1, showing the actual age profile in 2003 and the projected age profile in 2050, indicates that the relative size of the working-age population will decline and the population of ages 80 and over will increase substantially over the period.

The issue of population aging is more pronounced in the eastern part of the country. This is due to the low TFR, as well as the high migration rates of younger skilled workers from the east to more prosperous regions of the former West Germany following reunification in 1990. Two waves of outmigration, largely in reaction to economic conditions in the East, occurred in 1990, when 3.7 percent of the population migrated to the West, and in 1995-2002, when the outmigration rate from the eastern part of the country averaged 1.55 percent annually. These movements resulted in a significant loss of population in the eastern areas (Heiland, 2004). Since the 1970s the number of

\footnotetext{
${ }^{1}$ All projections are based on the Federal Statistical Office data, middle scenario, upper limit Statistisches Bundesamt (2006a).
} 
deaths has been greater than the number of births, and since 2004 these losses have not been compensated for by immigration (Grünheid, 2006). The shrinkage of the German population is expected to be accompanied by a contraction of the work force (ages 20-64) from about 50.1 million in 2003 to about 39.1 million in 2050. The projection corresponds to a 22 percent decrease in population from that of the scenario with high migration. The number of oldest old inhabitants (ages 80+) will triple until 2050.

\subsection{Social Security}

The German social security system is the oldest in the world. The first components (health care, insurance against accidents at work, disability, and old-age insurance) were introduced under Bismarck in the 1890s in response to pressure from the working class. The provision was significantly expanded over the twentieth century. Today, the system provides a wide range of benefits, including support for the unemployed, health care and long-term care, old-age and disability benefits, survivor pensions, child allowances, and monetary support for maternity leave. Contributions are financed equally by employers and employees. These contributions, which are subject to a monthly ceiling, go to pay for pensions (19.9 percent of gross wages), unemployment (6.5 percent), health care (about 14 percent), and long-term care (1.95 percent +0.25 percent for the childless). Social security contributions amounted to 17.3 percent of GDP in 2006 and are among the highest in Europe (Eurostat, 2008). Total government expenditures on social security make up 48.5 percent of GDP.

The German pension system began in 1889 as a capital funded system, with a waiting period of 30 years and a retirement age of 70 (Frerich and Frey, 1996, p. 100). It was reorganized as a pay-as-you-go pension scheme in 1957, when the capital stock was almost exhausted after the Great Depression and two world wars. The reforms that followed, especially in the 1970s, resulted in more generous arrangements. High replacement rates of about 70 percent of pre-retirement net earnings were introduced for workers with a 45-year earnings history and average lifetime earnings. Moreover, the mandatory retirement age of 65 for those with long working lives was abolished, enabling workers to retire earlier. As a result of these changes, pensions are now the single largest item in the social budget, with pensions amounting to 11 percent of GDP in 2003. A very large number of workers drop out of the labor force early, entering unemployment or

early retirement programs. In the 1990s reforms were introduced that were intended to eliminate certain generous features of the system and postpone effective retirement age, which is currently around age 61. For a thorough overview of the development of the 
German pension system, see Börsch-Supan and Wilke (2003). Today, the system covers 85 percent of the work force, and pensioners rely heavily on the public sector. Around 80 percent of the total income of pensioners comes from public pension transfer payments (Reil-Held, 2002, p.34f).

The health care system in Germany is mainly publicly financed, and its coverage is almost universal. About 88 percent of all Germans are insured by statutory health insurance, and fewer than 12 percent are insured in private insurance schemes. Contributions vary among the more than 200 public insurance companies. Government health expenditures amount to 136 billion euros, not including cash transfers and long-term care. Long-term care has its own budget of 17 billion euros in social security, which includes cash payments and in-kind transfers, depending on the degree of disability. About 12 percent of individuals aged 80 and over are in need of the services.

The German social security system also provides unemployment benefits that are based on compensation and years in employment. In 2003 the unemployed received up to 67 percent of their most recent net income (60 percent if childless) for at least six months, provided that they had been employed for at least 12 months. This period gradually increases to up to 32 months for people who were employed for at least six years. After the period of eligibility is over, people receive basic welfare benefits. The unemployment rate in 2003 was 9.3 percent (8.4 percent in 2007). A particular problem is the high long-term unemployment rate of 4.6 percent. Additionally, the unemployment rate among older people is extremely high. The employment rate of persons aged 55-64 was quite low in 2003, around 40 percent. The rate increased, however, by 10 percentage points between 2003 and 2008. Female employment rates amounted to only 58.9 percent in 2003, but by 2008 were 64 percent (Eurostat, 2008). More than 40 percent of women work part-time. Differences between eastern and western Germany are still present in various respects. The unemployment rate in the West was 8.4 percent in 2003, whereas in the East it was 18.5 percent (Bundesagentur für Arbeit, 2004). Many persons, especially among the elderly work force, receive unemployment benefits or partial retirement benefits (Altersteilzeitgeld). The dependence on public transfers for people of ages 65 and over is high in the western part of the country, as described above, but even more pronounced in the eastern part, where pensioners have virtually no additional income sources. 


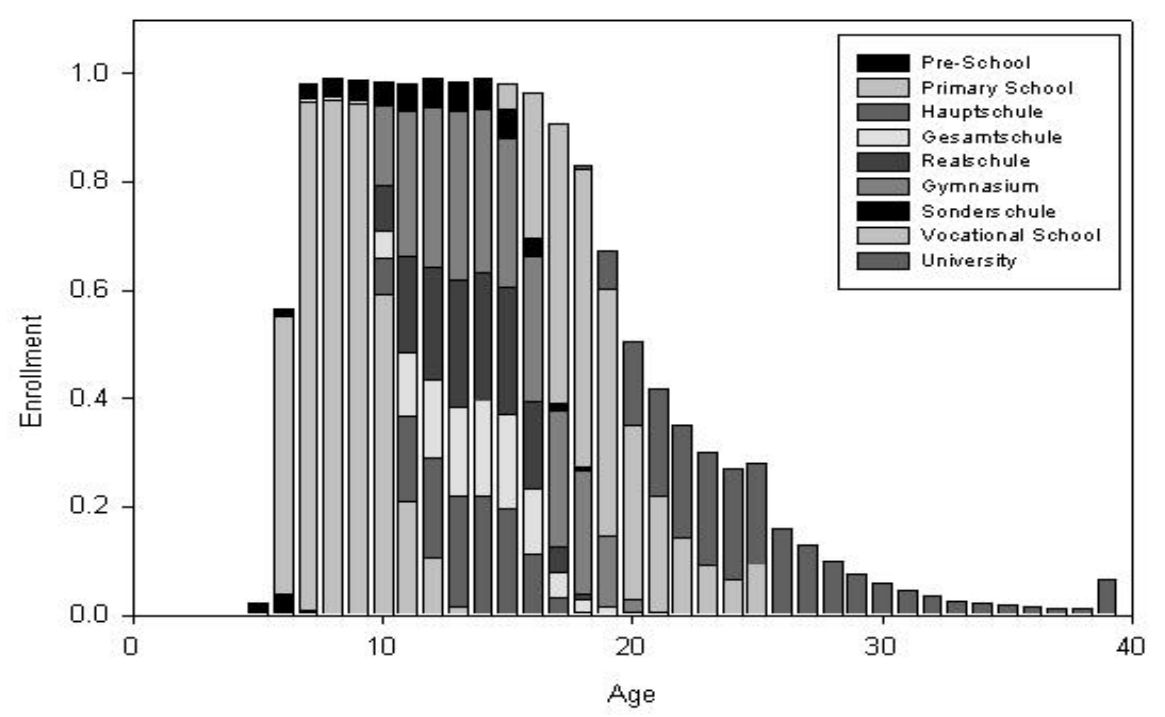

Figure 2: Enrollment by age and school type, Germany 2003 Source: Statistisches Bundesamt (2006b)

\subsection{The Education System}

The German education system is complex, with different policies applying in different parts of the country. In general, schools are publicly financed and free for everybody. Education is the responsibility of the individual German Länder. The education system is composed of 16 systems that vary in the number of mandatory years of schooling (usually around ten), ages for entry to primary and secondary school, and the types of schools offered. The total enrollment rate of children of ages 7-16 in public schools is about 98 percent. Only a negligible percentage of children are enrolled in private schools. All children attend the same type of primary school, usually starting at age 6 . After four or six years, depending on the school and the place of residence, children are enrolled in different types of schools according to their performance in primary school. The main categories for schooling up to age 16 are Gymnasium (which provides the most advanced level of education), Realschule, Hauptschule, and other hybrid forms. After completing the mandatory years of schooling, many students between the ages of 17 and 20 choose to attend a Berufsschule, or vocational school. Because students graduate from their Gymnasium or Berufsschule at relatively advanced ages, they tend to start tertiary education and complete their studies later than students in most other countries. The pattern of enrollment by age in the different school types is shown in Figure 2. 
The system is often criticized for being inflexible, resulting in too much time spent in education. Moreover, students who attend Hauptschule often face discrimination, as it represents the lowest level of education. The education system is undergoing change, however, especially at the tertiary level. Seven of the country's 16 states have started charging moderate tuition fees (about 500 euros per semester). Among those who must pay the fees are new students, almost all students enrolled for longer than ten semesters, and people who are studying for the second time.

\section{Materials and Methods}

\subsection{Methods}

NTA is a framework to quantify public and private interage reallocations in a crosssectional one year flow account. The economic lifecycle is fundamental feature of all economies regardless of their predominant redistributing institutions. Due to the economic dependency during childhood and old age large economic flows across age groups are the result, to finance everybody's needs (Mason, 2008a). The economic flows are measured across age groups in a systematic and comprehensive way, and identified by the economic mechanisms and mediating institutions (ibid.). The flow account identity is given by

$$
\underbrace{Y^{l}(a)+Y^{a}(a)+\tau^{+}(a)}_{\text {Inflows }}=\underbrace{C(a)+S(a)+\tau^{-}(a)}_{\text {Outflows }}
$$

where $Y^{l}(a)$ is the labor income, $Y^{a}(a)$ the asset income and $\tau^{+}(a)$ are the transfers received at each corresponding age a. $C(a), S(a)$ and $\tau^{-}(a)$ are consumption, savings and transfers paid at each age. The inflows need to equal the outflows. Rearranging 1 leads to

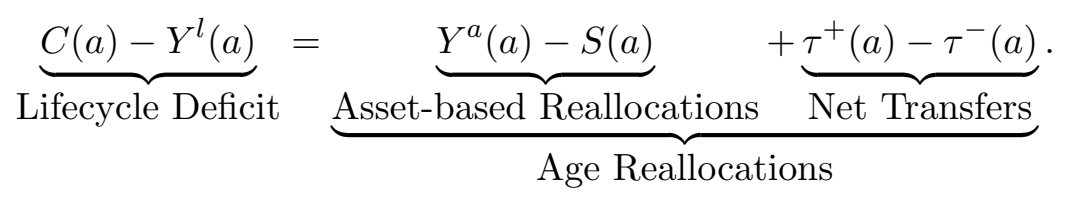

When we speak of the economic lifecycle, we refer to the cross-sectional age patterns (Lee et al., 2006). Interesting features are the crossing ages, when average individuals reach economic independence or fall back into dependency. Differing peak ages of income or the development of consumption at older ages can be illuminating as well. Interage flows can occur in form of transfers or as asset-based reallocations. For an overview see 
Table 1: A Classification of NTA Reallocations

\begin{tabular}{l|l|l|l}
\hline & \multicolumn{2}{|c}{ Asset-based Reallocations } & \\
& Capital & Credit & Transfers \\
\hline Public & Public Infrastructure & $\begin{array}{l}\text { Public debt } \\
\text { Student loans } \\
\text { Money }\end{array}$ & $\begin{array}{l}\text { Public education } \\
\text { Public health care } \\
\end{array}$ \\
& & Consumer credit & Unfunded pension plans \\
\hline Private & Housing & & Famililial support of \\
& Children and parents \\
& Factories & & Bequests \\
& Farms & & Charitable contribu- \\
& Inventories & & \\
\hline
\end{tabular}

Source: Adapted from Lee 1994

table 1. Transfers are defined as flows that involve no explicit quid pro quo (Mason, 2008a). Asset-based reallocations include credit, buying and selling assets, lifecycle saving, and intentional or accidental bequests. The accounts are accomplished by the different sectors. The private sector is dominated by the intra- and interhousehold transfers, but it also includes non-profit institutions serving households. The public sector includes cash and in-kind transfers, for example education, health or pensions. Emphasis is on age-related programs. The rest of the world is completing the sectors and includes remittances and international capital flows (Mason, 2008a).

The needed expenditures are only available on the household level in the EVS dataset, but individual level data by age is needed to compute the estimates. Therefore, a method similar to that in Attanasio et al. (1999) is employed; the total household expenditures on education are regressed on the number of household members enrolled in school and not enrolled in school, with the intercept suppressed (Lee et al., 2006).

$$
C_{H H}^{e d u}=\sum \alpha(a) E_{H H}(a)+\sum \beta(a) N E_{H H}(a) .
$$

Using numbers of household members in each age group as regressors, we then apply the same method for private health spending (ibid.). Other consumption is allocated using an equivalence scale. The allocation rule used is based on Deaton and Paxson (1997), who suggest that children age 0-4 count as 0.4 of an adult, children age 5-14 0.5, and children 15 and older as 1 . This equivalence scale is more continuous but similar, using 1 for persons age 20 and older and declining linearly to 0.4 at age 4 and younger (Lee et al., 2006). The private consumption profiles are smoothed afterwards and adjusted to their corresponding macro control to be consistent with the National Accounts.

All income variables and public transfer inflows and outflows are available in an EVS 
dataset for the individuals. The needed variables just need to be identified and then tabled over age. Afterwards the macro-adjustment factor $\theta$ is calculated in the following way:

$$
\theta=\sum x(a) N(a) / X
$$

where the age-specific expenditure share is multiplied by the population at that age and divided by the corresponding macro control. The macro adjustment factor for each item is used to adjust the expenditures and income to measure the intrahousehold transfers. An intrafamilial tax rate needs to be calculated to finance the consumption of household members having a deficit (for example children). These members receive intrafamililial transfers to finance their needs. Saving by definition is only possible for the household head.

\subsection{Data}

The estimates are based on national accounts and population estimates, both provided by the Federal Statistical Office (FSO) and the German Income and Expenditure Survey (Einkommens- und Verbrauchsstichprobe, or EVS). The national accounts published by the FSO follow the Europäischen System Volkswirtschaftlicher Gesamtrechnungen (ESVG) of 1995, which is based on the System of National Accounts of the United Nations (United Nations, 2002) of 1993. GDP is measured by the production and expenditure approach. (For information on the methodology, see Statistisches Bundesamt (2007b). The population estimates are available in one-year age groups provided by the German Federal Statistical Office, and are based on an extrapolation of last census data. The last censuses carried out in the former Federal Republic of Germany and the former German Democratic Republic were in 1987 and 1981, respectively. Additionally, publications of the Ministry of Health and Education are used in cases in which the national accounts and FSO statistics do not provide sufficient information.

The microlevel survey data are obtained from the EVS of 2003. The EVS is conducted every five years by the FSO, and is based on a representative quota sample of Germany's private households. The EVS includes a detailed account of income by source, consumption by type, saving flows, and asset stocks by portfolio category. The EVS of 2003 includes around 50,000 households made up of some 127,000 individuals. The waves from 1993 onward include not only the former Federal Republic, but also a sample from the former German Democratic Republic. The survey is representative of households with a monthly net income of less than 18,000 euros. The EVS does not include very wealthy households (70,000 of 38.1 million households), persons with no per- 
manent residence, or the institutionalized population. (For a methodological overview, see Statistisches Bundesamt (2005). For three months participating households keep a detailed book of household accounts that covers every kind of potential income and expenditure.

\section{Results Germany}

The first piece of NTA is the lifecycle deficit - as stated above, the difference between consumption and labor income at each age. Public consumption is broken down into three broad categories: education, health, and "other." The "other" category includes general public services, defense, public order and safety, economic affairs, environmental protection, housing and community amenities, recreation, culture, and religion. Public expenditures for items in that category are assumed to be non-age-specific and are therefore allocated equally to each of the 82 million individuals. Expenditures for education are costs related to schools and universities, excluding childcare facilities. The exclusion of childcare expenditures reduces the calculated cost of education by about 11 billion euros. The costs for each student enrolled in a particular school type are published by the FSO. For example, the annual cost of education is 3,900 euros for a child enrolled in primary school, 5,400 euros for a student attending Gymnasium, and 4,400 euros for a student in Realschule (Statistisches Bundesamt, 2006b). The costs are used as weighting factors for each school type and student. The age profile for public health expenditures is based on the costs of diseases published by the Gesundheitsberichterstattung des Bundes (Statistisches Bundesamt, 2007a). As the publications are available only for 2002 or 2004, the profile of 2004 is used for the year 2003. The two profiles do not vary much, and therefore the 2004 profile is assumed to be a good estimate for 2003. Because the costs for illnesses would add up to substantially higher expenditures on health, the profile is adjusted to the 136 billion euro figure for public health consumption that appears in the national accounts. Long-term care is also included in the picture, resulting in a steep rise in costs per capita above age 80 . Long-term care is not considered part of health expenditures in Germany, but rather as part of social security. A distinction must be made between long-term care in-kind transfers and cash transfers. Figure 3 includes only the 11 billion euros in long-term care in-kind transfers. The remaining part (about 6 billion) will be allocated to cash transfers that are not part of the lifecycle deficit. The combined age profiles show that individuals during childhood and old age consume higher levels of public benefits than do those at the ages in between. The high levels at younger ages are of course driven by education expenditures. Expenditures reach a peak at ages 12-15, 
when almost all German children are enrolled in secondary education, which is slightly more expensive than primary education. After age 16, expenditures start to decline. No age-specific data on education are available after age 39 . This simplification ignores a number of students; but, as the profiles are shown per capita, it would not make much difference. The relatively smooth public education profile is due to the overlapping of school types in Germany, as explained above. The increase in consumption during old age may be attributed to health care and long-term care expenditures.

Private consumption is estimated by using the EVS survey data. Household expenditures on education, health, imputed rental value of owner-occupied housing, durables, and other consumption are distinguished in the NTA framework. The age distribution of the household members and the usual NTA project methodology is followed in assigning household expenditures to individuals. The aggregate total, excluding indirect taxes, adjusts the microdata. Expenditures for private education are low in Germany. When we exclude costs for childcare from education, outlays for private education amount to only 0.7 percent of household expenditures. Because schools are free and publicly financed, education consumption is almost entirely included in public expenditures. The peak of the unsmoothed profile is at age 18; most other ages fluctuate at a lower level. This picture could change in the future as universities introduce tuition fees (as described above), and schools begin allowing parents to pay for books and other resources. On average, private health care expenditures amount to 4 percent of household expenditures but rise with age. The peak is reached at age 77 and declines thereafter. The main expenditures for health care are again publicly financed; for the most part, the system provides health care for free. Imputed rental value of owner-occupied housing is modest in Germany. The homeownership rate in Germany is only about 40 percent, much lower than in other countries (Börsch-Supan et al., 2001, p. 22). Household imputed rent is allocated to individuals in the same way that other private consumption is. Durables are allocated in the same way and treated as final consumption. Total private consumption has a double hump-shaped pattern over the lifecycle. In Germany it is dominated mainly by "other" consumption, which is allocated by means of an equivalence scale ${ }^{2}$. As stated above, most expenditure that is age-specific (education and health) is low in Germany. All other expenditures-including food, clothes, and water-dominate the picture.

Labor income consists of income from earnings and from self-employment. Most labor income results from earnings; income from self-employment is comparatively low. After

\footnotetext{
${ }^{2}$ An equivalence scale is used to allocate individual consumption for "other" as well as for capital consumption and durables. It follows the calculation $1-0.6^{*} \mathrm{I}(4<\mathrm{x}<20) *[(20-\mathrm{x}) / 16]-0.6^{*} \mathrm{I}(\mathrm{x} \leq 4)$ where $\mathrm{I}($. $)$ is the indicator function.
} 


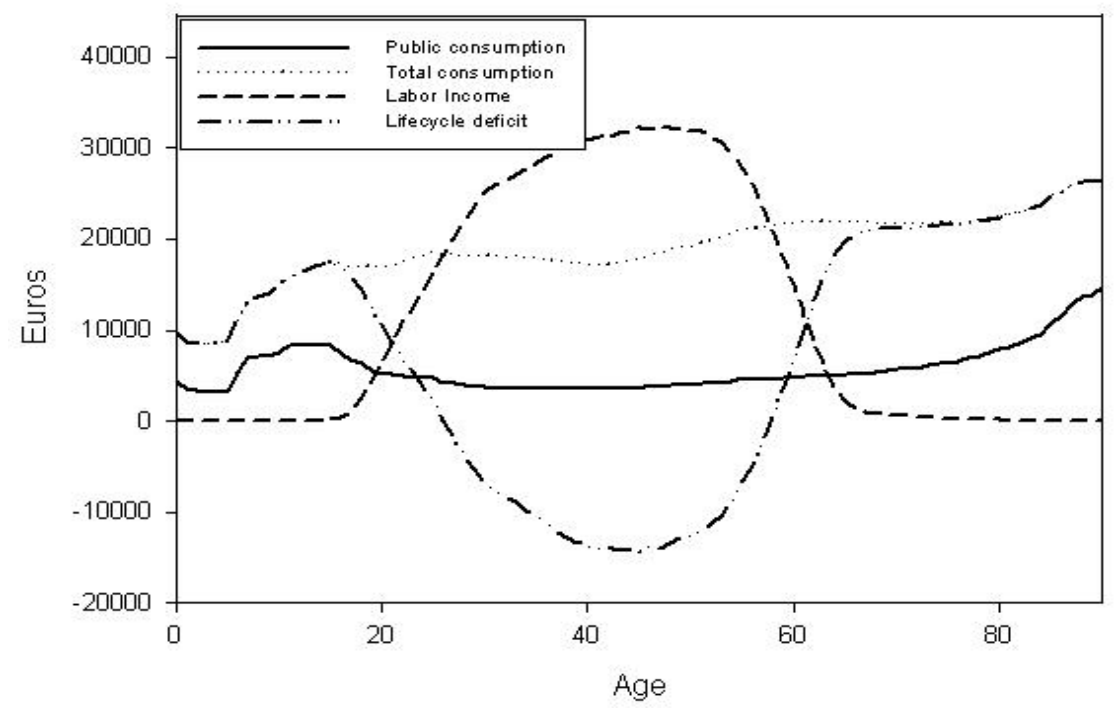

Figure 3: The lifecycle deficit and its components, Germany 2003

Source: various sources described above, author's own calculations

age 55 , the profile decreases quickly. This is probably due to Germany's generous early retirement provisions and the lack of incentives to stay in the labor force, as described in Börsch-Supan and Jürges (2007) and elsewhere.

By combining consumption and labor income profiles, one obtains the lifecycle deficit. The LCD for Germany in 2003, shown in Figure 3, reveals turning points at age 27, when the productive period begins, and at age 57, which marks an early exit from that period (productivity in this case referring to the time when labor earnings exceed consumption). At just 30 years, the German economic lifecycle has a rather short period of surplus. The brevity of this productive period may be attributed to the late departure from childhood dependency probably due to long periods spent in education, the early exit from the labor force due to early retirement provisions, and the high unemployment rates for people of ages 50 and over. Although Germany's education system is comparable to the Austrian system (Austria also traditionally has apprenticeships and a rather low percentage of students in tertiary education), the initial entry into the productive period in the early 20s there cannot be found in the German profiles.

Figure 4, which contrasts the normalized LCD for Germany with that of Austria and Finland, shows that, especially at younger ages, the countries are very much alike. Although they follow comparable patterns, there is a divergence at the end of life due 


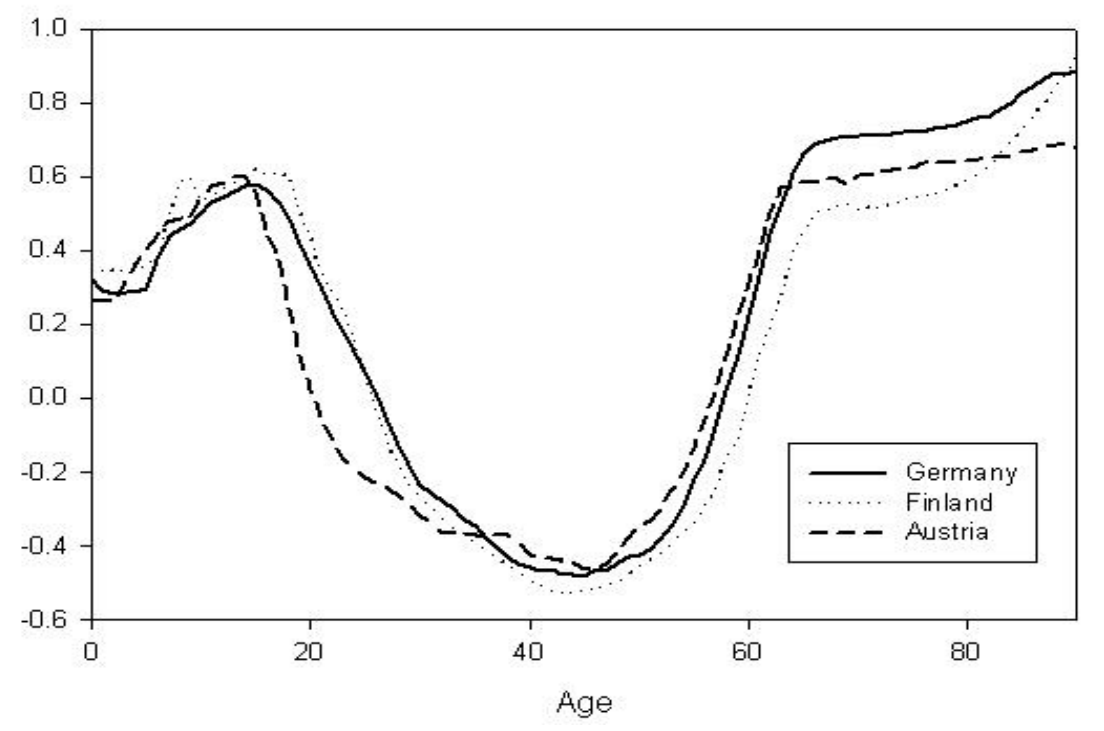

Figure 4: The normalized lifecycle deficit for Austria, Finland and Germany Source: NTA project estimates, author's own calculations

to differing institutional provisions for old age. In particular, the inclusion of long-term care provisions alters the picture. The lifecycle deficit in Germany after age 57 develops rather steeply and quickly reaches a deficit of 70 percent of a prime-age adult incomea level first reached about ten or more years later in other developed countries. The aging of the population makes this an issue of particular concern. With the population's life expectancy at more than 80 years and its productive period at only 30 years, the German welfare state, with its generous provisions, will quickly face bigger sustainability problems than it does today, as all leading economists point out. The government has undertaken initial steps to lengthen the working life of individuals, which in turn will help reform the system by lengthening the surplus period.

As shown above, the in-kind public transfers are beneficial for young and old individuals. In contrast to this, public transfer cash inflows are mainly for the elderly, with pensions dominating the picture. Whereas the inflows for the young amount to slightly less than 9,000 euros per capita, the annual inflows for the elderly amount to more than 20,000 euros. Inflows include the public consumption items explained above, child allowance, parental leave benefits, unemployment benefits, long-term cash payments, and widow's pensions to name the most prominent items. Outflows are mainly paid by the working aged population via income tax and social contributions. Furthermore it 


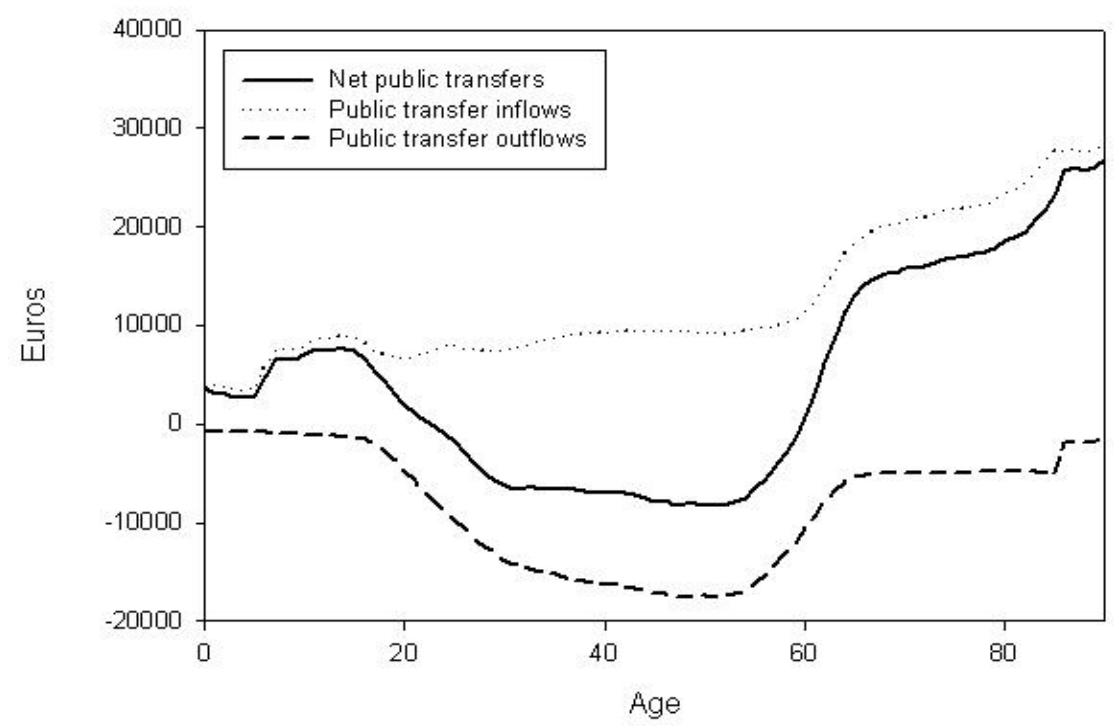

Figure 5: Public cash transfers, Germany 2003

Source: EVS, National Accounts, author's own calculations

includes value added taxes paid by all individuals that consume (also children). The elderly pay for health care and property income taxes additionally. As the other social protection category includes unemployment benefits and child allowances that by definition are paid to the household head ${ }^{3}$, the intragenerational redistribution amounts a substantial part in social security. The net public transfer flows are shown in figure 5 .

To complete the transfer part, we have to include the private transfers into the calculations. These part consists of inter- and intrahousehold transfers and complete the transfers. High inflows can be noted for the young as they get intrafamily transfers to finance their consumption. The turning point when household members become net givers is at age 30. From there on it remains negative for the rest of life. The private transfers within the family are shown in figure 6 .

\section{Preliminary Results for East and West}

The history of Germany in the last century is closely interweaved with the Cold War; after the second world war it was divided into an eastern part under Sovjet authority

\footnotetext{
${ }^{3}$ Child allowance as a cash transfer is an inflow to the household head as it is not certain that the child benefits. So the children do get intrafamily transfers for their own consumption rather than an own "income".
} 


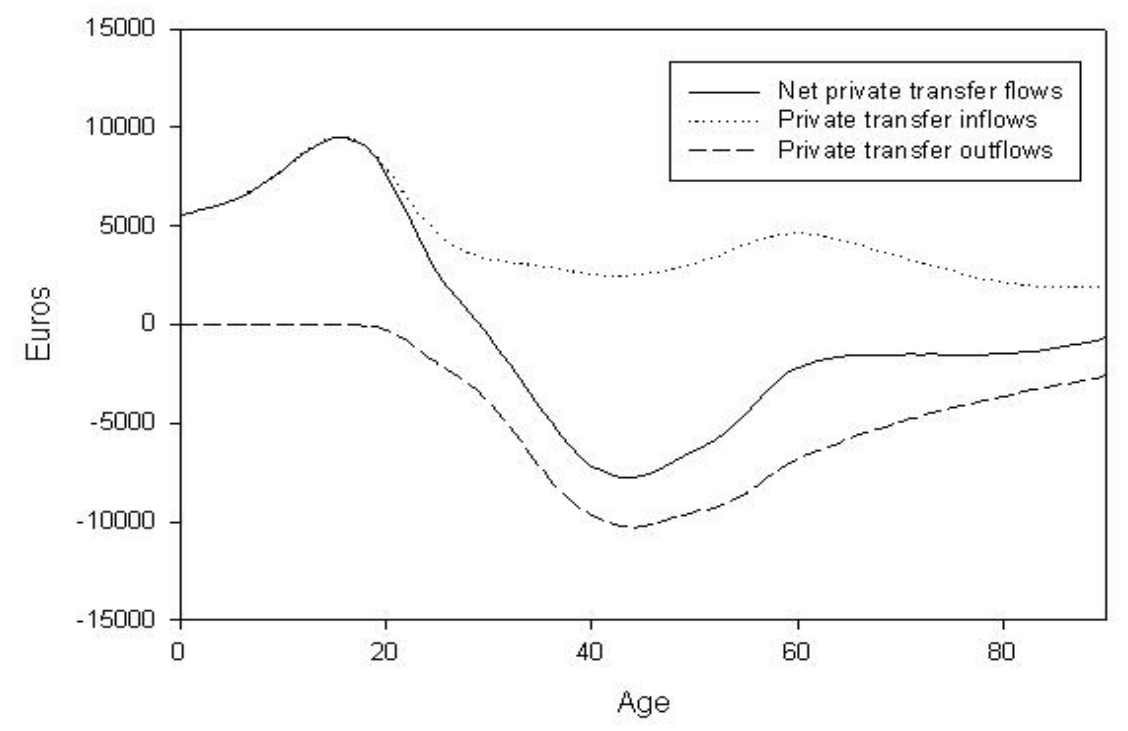

Figure 6: Private transfers (intrahousehold), Germany 2003 Source: EVS, National Accounts, author's own calculations

and a western part governed by the western Allies. Four decades, the two Germanies were apart, experiencing a history that could not be more different. In November 1989, surprisingly and in rapid development the Fall of the Berlin Wall took place, followed by the unification process of the former Federal Republic of Germany and the German Democratic Republic. The new Länder of eastern Germany had to undertake the transformation of state-owned, centrally planned and managed economic systems into functioning capitalist market economies (Baylis, 1993, p. 77). The unification was implemented with remarkable haste, already half a year after the Wall opening, the two Germanies signed a treaty on monetary, economic, and social union; the "GDR ceded its financial sovereignty to the Federal Republic and committed itself to building a "social market economy', and bringing its tax, welfare and labor laws in line with the West's" (Baylis, 1993, p.80). The economic unification including the extension of the West German mark to the GDR, as well as western social and economic benefits to the East was driven by the continuing waves of East Germans leaving for the West (Hanhardt, 1993, p. 226f.). Since then the topic of East and West never vanished from the agenda, mainly due to the different economic and demographic situation in the different parts. The eastern part until today suffers from outmigration of the young skilled people as well as poor economic performance and high unemployment rates (as described in section 2) 
whereas the conditions in the West are in general perceived to be better.

Figure 7 and figure 8 show the main income sources in East and West by age, 12 years after Reunification. During childhood, until about age 16, consumption is financed by parents. The percentage of persons dependent on a spouse or parents remains at about 20 percent after age 30 in the western part, double as high as in the east. The employed status follows the same pattern as the labor income profile and is in percentage points about the same for the two parts. Noteworthy are persons receiving unemployment benefits and on partial retirement (Altersteilzeit). A relatively high percentage of people of ages 50 and over have left the labor market and must bridge the gap to pension income in the east. 20 percent of the elderly are on unemployment benefits, another about 10 percent in partial retirement programs. The values are more than twice as high as for the western part. Pensioners in the East mainly live on public pensions, they have hardly any other income source. In the West it is only 80 percent and the category "other" including assets is more frequent.

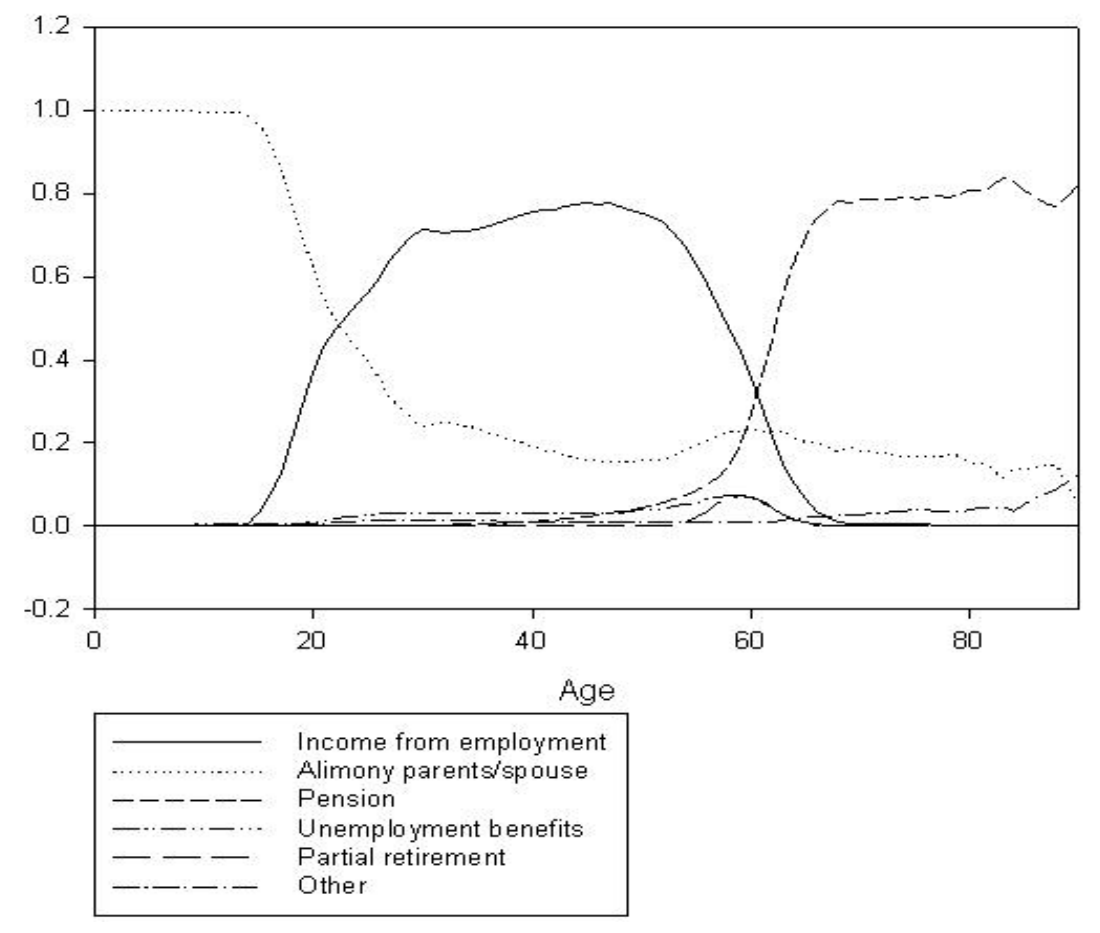

Figure 7: Income source by age, West 2003, Source: EVS 2003

The normalized lifecycle deficit for East and West Germany is shown in figure 9. The LCD is normalized to labor income of people age 30 to 49. The productive period starts 


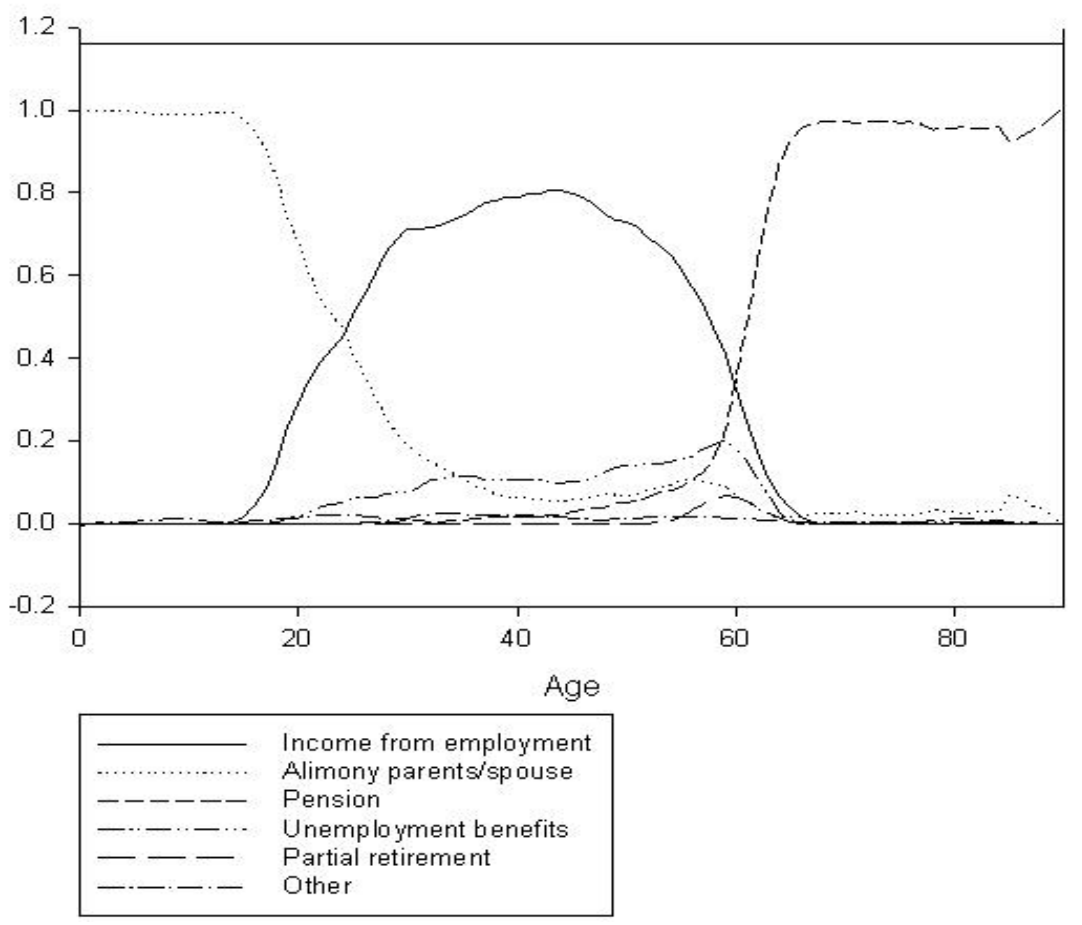

Figure 8: Income source by age, East 2003, Source: EVS 2003

one year later in the East and it ends already at age 55 which is 3 years earlier than in the western part. It is not only shorter but higher throughout all age groups. As wages are lower in the eastern part, a 15-year old consumes 70 percent of an average income of people age 30-49 whereas in the western part it is only 56 percent. These values are even higher for the elderly population. Above age 80 eastern pensioners consume almost 100 percent of an prime age adult income, in the western part it is only around 80 percent. Noteworthy is the dramatic decline after age 45 in the East. This is due to the high unemployment rates of the elderly as shown above. Another interesting aspect is the volatile profile for the East, it is by far not as smooth as the western normalized lifecycle deficit.

\section{Conclusion}

The labor income profile for Germany in 2003 follows the usual pattern, with a slightly more pronounced decrease at older ages. Total consumption is smooth, and it increases over the lifecycle. Private consumption of health and education amounts to low per- 


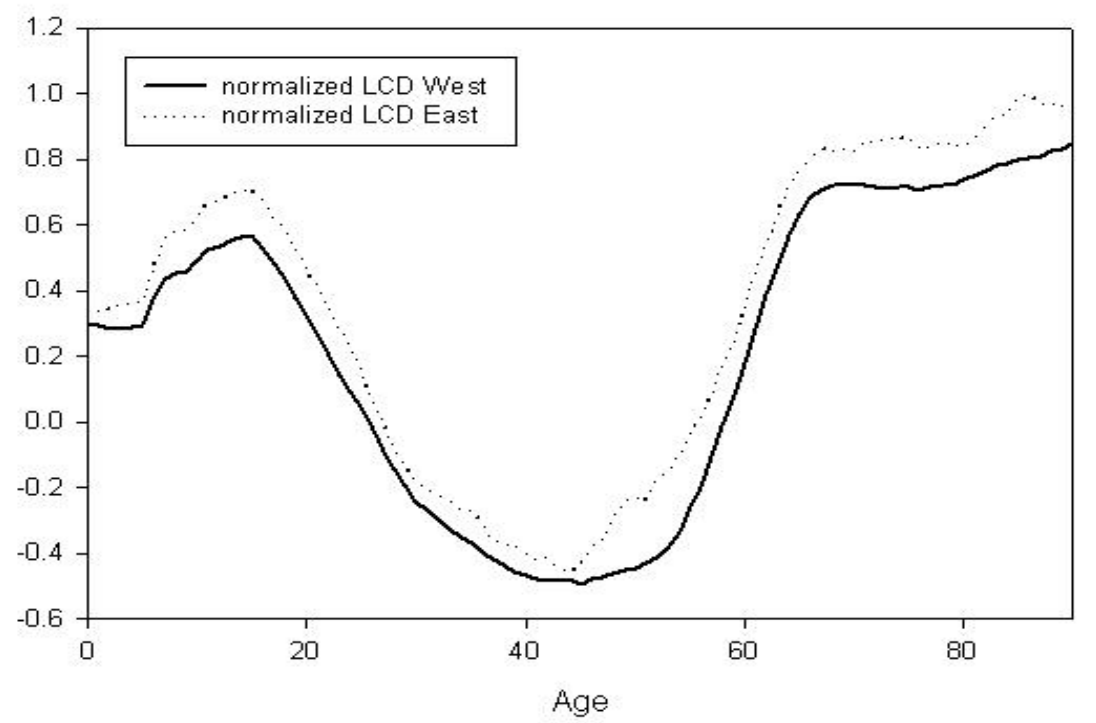

Figure 9: The lifecycle deficit for East and West 2003

Source: various sources described above, author's own calculations

centages of household expenditures, whereas the public sector bears nearly all of the associated costs. The German lifecycle deficit for 2003 shows a period of surplus of about 30 years (from age 27 to age 57). Because of the German education system, the productive period starts late, and high unemployment rates among older workers and incentives to retire early result in an early end to the productive period. Public transfers show large in-kind public transfer inflows at both ends of life, whereas cash transfers are skewed to the elderly, dominated by expenditures on pensions. Private transfers are directed from old to young, even the oldest old give more than they receive and have a negative net flow.

The lifecycle deficit estimated for the eastern part shows a four year shorter surplus period and substantially higher deficits at young and old ages than its western counterpart. The surplus period already ends at age 55, mainly due to a high percentage of people age 45 and older receiving unemployment benefits or participating in partial retirement programs. The public transfer dependency is especially for the older inhabitants much more pronounced and results in substantial intragenerational redistribution from the work force to the people in need. A question remains whether this is a temporary pattern evolved because of historic reasons or if this is permanent. Future research will focus on the construction of a complete set of NTA for East and West as well as 
historic estimates.

\section{References}

Attanasio, O. P., Banks, J., Meghir, C., and Weber, G. (1999). Humps and Bumps in Lifetime Consumption. Journal of Business $\&$ Economic Statistics, 17(1):22-35.

Auerbach, A., Gokhale, J., and Kotlikoff, L. (1991). Generational Accounts-A Meaningful Alternative to Deficit Accounting. National Bureau of Economic Research Cambridge, Mass., USA.

Auerbach, A., Kotlikoff, L., and Leibfritz, W. (1999). Generational Accounting Around the World. University of Chicago Press.

Auerbach, A. J., Gokhale, J., and Kotlikoff, L. J. (1992). Generational Accounting: A New Approach to Understanding the Effects of Fiscal Policy on Saving. The Scandinavian Journal of Economics, 94(2):303-318.

Auerbach, A. J., Gokhale, J., and Kotlikoff, L. J. (1994). Generational Accounting: A Meaningful Way to Evaluate Fiscal Policy. The Journal of Economic Perspectives, 8(1):73-94.

Baylis, T. (1993). Transforming the East German Economy: Shock without Therapy. In From Bundesrepublik To Deutschland. German Politics after Unification, pages 77-92. Huelshoff, Markovits and Reich (eds.).

Boll, S., Raffelhüschen, B., and Walliser, J. (1994). Social security and intergenerational redistribution: A generational accounting perspective. Public Choice, 81(1):79-100.

Bommier, A. and Lee, R. (2003). Overlapping generations models with realistic demography. Journal of Population Economics, 16(1):135-160.

Börsch-Supan, A. (1992). Saving and consumption patterns of the elderly. Journal of Population Economics, 5(4):289-303.

Börsch-Supan, A. and Jürges, H. (2007). Early Retirement, Social Security and WellBeing in Germany. MEA Discussion Paper.

Börsch-Supan, A., Reil-Held, A., Rodepeter, R., Schnabel, R., and Winter, J. (2001). The German Savings Puzzle. Research in Economics, 55(1):15-38. 
Börsch-Supan, A. and Schnabel, R. (1999). Social Security and Retirement in Germany. In Gruber, J.; Wise, D., editor, Social Security and Retirement around the World, pages $135-80$. University Of Chicago Press.

Börsch-Supan, A. and Wilke, C. (2003). The German Public Pension System: How it Was, How it Will Be. MEA Discussion Paper.

Bundesagentur für Arbeit (2004). Arbeitsmarkt 2003. Amtliche Nachrichten der Bundesagentur für Arbeit, 52. Jahrgang, Sondernummer.

Deaton, A. S. and Paxson, C. H. (1997). The Effects of Economic and Population Growth on National Saving and Inequality. Demography, 34(1):97-114.

Diamond, P. (1965). National Debt in a Neoclassical Growth Model. The American Economic Review, 55(5):1126-1150.

Eurostat (2008). Yearbook 2008: Europe in figures.

Frerich, J. and Frey, M. (1996). Handbuch der Geschichte der Sozialpolitik in Deutschland, Vol. 1: Von der vorindustriellen Zeit bis zum Ende des Dritten Reiches. Verlag Oldenburg, München.

Grünheid, E. (2006). Die demographische Lage in Deutschland 2005. Zeitschrift für Bevölkerungswissenschaft, 31(1):3-104.

Grünheid, E. and Mammey, U. (1997). Bericht 1997 über die demographische Lage in Deutschland. Zeitschrift für Bevölkerungswissenschaft, 22(4):377-480.

Hanhardt, A. (1993). The collapse of the german democratic republic and its unification with the federal republic of germany, 1989-90. In From Bundesrepublik To Deutschland. German Politics after Unification. Huelshoff, Markovits and Reich (eds.).

Heiland, F. (2004). Trends in East-West German Migration from 1989 to 2002. Demographic Research, 11(7):173-194.

Kohli, M., Künemund, H., Motel, A., and Szydlik, M. (2006). Families Apart? Intergenerational Transfers in East And West Germany. The Myth of Generational Conflict: The Family and State in Ageing Societies, pages 88-99.

Lee, R. (1994). The Formal Demography of Population Aging, Transfers, and the Economic Life Cycle. National Academy Press Washington, DC 1994, pages 8-49. 
Lee, R., Lee, S., and Mason, A. (2006). Charting the Economic Life Cycle. In Population Aging, Human Capital Accumulation, and Productivity Growth, pages 208-237. A. Prskawetz, D. E. Bloom and W. Lutz., New York, Population Council.

Lüth, E. (2001). Private Intergenerational Transfers and Population Aging: The German Case. Physica Verlag.

Mason, A. (2005). An Overview of National Transfer Accounts. National Transfer Account Overview Paper, www.ntaccounts.org.

Mason, A. (2006). Population Aging and intergenerational transfers: introducing age into national accounts. NBER Working Paper. NBER Working Paper Series.

Mason, A. (2008a). An overview of national transfer accounts. In Presentation during the 39th Summer Seminar on Population, Workshop 1.

Mason, A. (2008b). Sustainable Economic Policies in an Aging World, presented at the Shanghai Forum 2008: Economic Globalization and the Choice of Asia.

Raffelhüschen, B. and Walliser, J. (1999). Unification and Aging in Germany: Who Pays and When. Generational Accounting Around the World, Chicago, London, pages 277-297.

Reil-Held, A. (2002). Die Rolle intergenerationaler Transfers in Einkommen und Vermögen älterer Menschen in Deutschland. Mannheim: Universität Mannheim.

Samuelson, P. A. (1958). An Exact Consumption-Loan Model of Interest with or without the Social Contrivance of Money. The Journal of Political Economy, 66(6):467-482.

Statistisches Bundesamt (2005). Einkommens- und Verbrauchsstichprobe-Aufgabe, Methode und Durchführung der EVS. [Income and Expenditure Survey-task, method and carrying out of EVS]. . Fachserie 15, Heft 7.

Statistisches Bundesamt (2006a). 11. koordinierte Bevölkerungsvorausberechnung [11th coordinated population projection. Estimates and results.]. Annahmen und Ergebnisse, Wiesbaden.

Statistisches Bundesamt (2006b). Im Fokus: Ausgaben je Schüler/-in 2003 [In focus: Expenses per student in 2003]. Wiesbaden.

Statistisches Bundesamt (2007a). Gesundheit-Krankheitskosten 2002 und 2004 [Health care-Disease expenses, 2002 and 2004]. Wiesbaden. 
Statistisches Bundesamt (2007b). Volkswirtschaftliche Gesamtrechnungen, Inlandsprodukt nach ESVG 1995, Methoden und Grundlagen. [Overall economic calculations, domestic product according to ESVG]. Fachserie 18, Reihe S. 22.

United Nations (2002). Handbook of National Accounting. Series F, No. 81.

Willis, R. (1988). Life cycles, institutions and population growth: A theory of the equilibrium interest rate in an overlapping-generations model. Economics of Changing Age Distributions in Developed Countries, pages 106-38. 